\title{
Magnetic susceptibility and NEXAFS spectra of Fe, Mg-codoped bismuth niobate pyrochlore
}

\author{
N. A. Zhuk ${ }^{\dagger, 1}$, B. A. Makeev², S. V. Nekipelov ${ }^{3}$, R. I. Korolev' ${ }^{1}$, A. A. Utkin ${ }^{1}$, G. I. Chernykh ${ }^{1}$ \\ †nzhuck@mail.ru
}

\author{
${ }^{1}$ Syktyvkar State University, Syktyvkar, 167001, Russia \\ ${ }^{2}$ Institute of Geology of the Komi Science Center UB RAS, Syktyvkar, 167982, Russia \\ ${ }^{3}$ Institute of Physics and Mathematics of the Komi Science Center UB RAS, Syktyvkar, 167982, Russia
}

Compounds with the pyrochlore structure are attracting inexhaustible interest of scientists due to the manifestation of a wide range of practically useful properties, including dielectric, photocatalytic and magnetic ones. The present work reports on the results of the study by NEXAFS spectroscopy and the static magnetic susceptibility of the electron state and the character of interatomic interactions of iron atoms in Fe-doped of multicomponent bismuth niobate pyrochlore (sp.gr. Fd-3m). Iron-containing solid solutions of the $\mathrm{Bi}_{2} \mathrm{MgNb}_{2-2 x} \mathrm{Fe}_{2 x} \mathrm{O}_{9-\delta}(x \leq 0.06)$ composition with the pyrochlore structure were synthesized by the solid-phase method. The lattice constant of dilute solid solutions changes insignificantly with increasing iron content and is close to the parameter of bismuth-magnesium niobate. According to X-ray spectroscopy and magnetic susceptibility data, iron atoms are distributed mainly in the octahedral positions of niobium (V) and are in the dominant amount in the $\mathrm{Fe}$ (III) charge state in the form of monomers and highly nuclear exchange-bound clusters with predominantly antiferromagnetic exchange. The parameters of exchange interactions in clusters and the distribution of paramagnetic iron atoms are calculated depending on the concentration of $\mathrm{Bi}_{2} \mathrm{MgNb}_{2-2 x} \mathrm{Fe}_{2 x} \mathrm{O}_{9-\delta}$ solid solutions. The best agreement between the experimental and calculated values of the paramagnetic component of the magnetic susceptibility for $\mathrm{Bi}_{2} \mathrm{MgNb}_{2-2 x} \mathrm{Fe}_{2 x} \mathrm{O}_{9-\delta}$ solid solutions was achieved at the following values of the antiferromagnetic exchange parameters in dimers $J_{\operatorname{dim}}=-25 \mathrm{~cm}^{-1}$, in trimers $J_{\text {trim }}=-14 \mathrm{~cm}^{-1}$ and tetramers $J_{\text {tetr }}=-9 \mathrm{~cm}^{-1}$ and ferromagnetic exchange in dimers $-J_{\text {dim }}=20 \mathrm{~cm}^{-1}$, in trimers $J_{\text {trim }}=16 \mathrm{~cm}^{-1}$ and tetramers $J_{\text {tetr }}=11 \mathrm{~cm}^{-1}$.

Keywords: magnetic properties, pyrochlore, iron, NEXAFS.

УДК: 537.3, 537.9, 538.9

\section{Магнитная восприимчивость и NEXAFS спектры ниобата висмута со структурой пирохлора, допированного магнием и железом}

\author{
Жук Н. А. ${ }^{\dagger}, 1$ Макеев Б. А. ${ }^{2}$, Некипелов С. В. ${ }^{3}$, Королев Р.И. ${ }^{1}$, Уткин А. А. ${ }^{1}$ Черных Г.И. ${ }^{1}$ \\ ${ }^{1}$ Сыктывкарский государственный университет, Сыктывкар, 167001, Россия \\ ${ }^{2}$ Институт геологии Коми НЦ УрО РАН, Сыктывкар, 167982, Россия \\ ${ }^{3}$ Институт физики и математики Коми НЦ УрО РАН, Сыктывкар, 167982, Россия
}

Соединения со структурой пирохлора вызывают неиссякаемый интерес ученых в связи с проявлением широкого спектра практически полезных свойств, среди которых диэлектрические, фотокаталитические, магнитные. В представленной работе показаны результаты исследования методами NEXAFS и статической магнитной восприимчивости электронного состояния и характера межатомных взаимодействий атомов железа в сложном ниобате висмута со структурой пирохлора (пр.гр. Fd-3m). Твердофазным методом синтезированы железосодержащие твердые растворы состава $\mathrm{Bi}_{2} \mathrm{MgNb}_{2-2 x} \mathrm{Fe}_{2 x} \mathrm{O}_{9-\delta}(x \leq 0.06)$ со структурой пирохлора. Постоянная решетки разбавленных твердых растворов незначительно изменяется с ростом содержания железа и близка параметру ниобата висмута-магния. По данным рентгеновской спектроскопии и магнитной восприимчивости атомы железа распределяются преимущественно в октаэдрические позиции ниобия (V) и в доминирующем количестве находятся в зарядовом состоянии Fe (III) в форме мономеров и высоконуклеарных обменносвязанных кластеров преимущественно с антиферромагнитным типом обмена. Проведен расчет параметров обменных взаимодействий 
в кластерах и распределения парамагнитных атомов железа в зависимости от концентрации твердых растворов $\mathrm{Bi}_{2} \mathrm{MgNb}_{2-2 x} \mathrm{Fe}_{2 x} \mathrm{O}_{9-\delta}$. Наилучшее согласие экспериментальных и расчетных значений парамагнитной составляющей магнитной восприимчивости для твердых растворов $\mathrm{Bi}_{2} \mathrm{MgNb}_{2-2 x} \mathrm{Fe}_{2 x} \mathrm{O}_{9-\delta}$ достигнуто при следующих значениях параметров антиферромагнитного обмена в димерах $J_{\text {дим }}=-25 \mathrm{~cm}^{-1}$, в тримерах $J_{\text {трим }}=-14 \mathrm{~cm}^{-1}$ и тетрамерах $J_{\text {тетр }}=-9 \mathrm{~cm}^{-1}$ и ферромагнитного обмена в димерах $-J_{\text {дим }}=20 \mathrm{~cm}^{-1}$, в тримерах $J_{\text {трим }}=16 \mathrm{~cm}^{-1}$ и тетрамерах $J_{\text {тетр }}=11 \mathrm{~cm}^{-1}$.

Ключевые слова: магнитные свойства, пирохлор, железо, NEXAFS.

\section{Introduction}

Compounds with the pyrochlore structure are attracting inexhaustible interest of scientists in connection with the manifestation of a wide range of practically useful properties, such as photocatalytic, dielectric, electrooptical and piezoelectric properties [1-5]. In the cubic structure of pyrochlore (general formula $\mathrm{A}_{2} \mathrm{~B}_{2} \mathrm{O}_{7}$, sp.gr. $\mathrm{Fd}-3 \mathrm{~m}$ ), large eight-coordinated $\mathrm{A}$ cations $(\mathrm{Bi}, \mathrm{Pb}, \mathrm{Nd}, \mathrm{Sm}, \mathrm{Eu})$ and relatively small octahedral B cations $(\mathrm{Ru}, \mathrm{Ir}, \mathrm{Ta}, \mathrm{Nb}, \mathrm{Ti}, \mathrm{Zr}$, $\mathrm{Sn}, \mathrm{Hf}, \mathrm{Sb}, \mathrm{Te})$ are located $[3,6]$. The structure contains two interpenetrating weakly interacting sublattices $\mathrm{A}_{2} \mathrm{O}^{\prime}$ and $\mathrm{B}_{2} \mathrm{O}_{6}$. The $\mathrm{B}_{2} \mathrm{O}_{6}$ sublattice consists of $\left[\mathrm{BO}_{6}\right]$ octahedra connected at the vertex of the angle; the $\mathrm{A}_{2} \mathrm{O}^{\prime}$ sublattice has an anticristobalite structure and is formed by $\left[\mathrm{O}^{\prime} \mathrm{A}_{4}\right]$ tetrahedra. Triple pyrochlores containing transition metals are of particular interest [7-10]. The advantage of bismuthcontaining ternary pyrochlores is associated with the possibility of replacing $\mathrm{Bi}^{3+}$ cations in A-positions with small $\mathrm{C}$ cations ( $\mathrm{Mg}, \mathrm{Cu}, \mathrm{Ni}, \mathrm{Cr})$.

As a result, the same ions can occupy two nonequivalent positions A and B. This feature of the distribution of cations of transition elements in bismuth niobate with a pyrochlore structure was noted in $[8,9]$. Complex bismuth-containing pyrochlores are distinguished by their excellent dielectric properties [11,12]. Among pyrochlores based on bismuth oxide, the maximum dielectric constant and the smallest dielectric loss tangent are shown by $\mathrm{Bi}_{2} \mathrm{Mg}_{2 / 3} \mathrm{Nb}_{4 / 3} \mathrm{O}_{7}$ [11-13], $\mathrm{Bi}_{2}\left(\mathrm{Zn}_{1-x} \mathrm{Ni}_{x}\right)_{2 / 3} \mathrm{Nb}_{4 / 3} \mathrm{O}_{7} \quad$ [14], $\quad \mathrm{Bi}_{2-x} \mathrm{La}_{x} \mathrm{Mg}_{2 / 3} \mathrm{Nb}_{4 / 3} \mathrm{O}_{7} \quad$ [15], $\mathrm{Cu}$-doped $\mathrm{Bi}_{2} \mathrm{Mg}_{2 / 3} \mathrm{Nb}_{4 / 3} \mathrm{O}_{7}[16]$. They are distinguished by a relatively low synthesis temperature and chemical inertness to Ag electrodes [17]. A useful circumstance is the fact that complex bismuth-containing pyrochlores correspond to wide regions of homogeneity due to the structural flexibility of the pyrochlore crystal lattice [7-9]. Being within the same structural type and changing the qualitative and quantitative compositions, one can significantly vary the properties of pyrochlore, which makes it possible to study the effect of the chemical composition on its physicochemical characteristics.

The presented work shows the results of the study by NEXAFS spectroscopy and the static magnetic susceptibility of the electron state and the character of interatomic interactions of iron atoms in Fe-doped multicomponent bismuth niobate pyrochlore.

\section{Experimental}

The synthesis of $\mathrm{Bi}_{2} \mathrm{MgNb}_{2-2 x} \mathrm{Fe}_{2 x} \mathrm{O}_{9-\delta}$ solid solutions was carried out by the standard ceramic method from oxides of bismuth (III), niobium (V), magnesium (II) and iron (III) of special purity grade using stage-by-stage annealing at temperatures of $650,850,950$ and $1100^{\circ} \mathrm{C}$. The phase composition of the samples was monitored using X-ray phase analysis (DRON-4-13 X-ray diffractometer, $\mathrm{Cu}_{\mathrm{K} \alpha}$ emission) and scanning electron microscopy (Tescan VEGA 3LMN electron scanning microscope, INCA Energy 450 energy dispersion spectrometer). The unit cell parameters of the preparations were calculated using the CSD software package [18]. The magnetic susceptibility of solid solutions was measured by the Faraday method in the temperature range $77-400 \mathrm{~K}$ (at 16 fixed values) and at magnetic field strengths of 7240, 6330, 5230 and 3640 Oe. The accuracy of relative measurements was $2 \%$. Samples of solid solutions were studied by X-ray absorption spectroscopy (NEXAFS Near Edge X-ray Absorption Fine Structure) using synchrotron radiation from the BESSY II storage device (Berlin, Germany). NEXAFS spectra were obtained by the Total electron yield (TEY) mode [19].

\section{Results and discussion}

\subsection{X-ray phase analysis and microstructure}

The formation of solid solutions of the composition $\mathrm{Bi}_{2} \mathrm{MgNb}_{2-2 x} \mathrm{Fe}_{2 x} \mathrm{O}_{9-\delta}(x \leq 0.06)$ was established by XRD and electron scanning microscopy (Figs. 1a, b).

The calculation of the unit cell parameters showed that the lattice constant of $\mathrm{Bi}_{2} \mathrm{MgNb}_{2-2 x} \mathrm{Fe}_{2 x} \mathrm{O}_{9-\delta}$ dilute solid solutions changes slightly with an increase in the iron content $a=1.05579 \mathrm{~nm}(x=0.01)$ and $a=1.05576 \mathrm{~nm}(x=0.04)$ and is close to the parameter of bismuth-magnesium niobate with pyrochlore structure [13-15]: $a=1.056 \mathrm{~nm}$. This change in the cell parameter may be due to isomorphic substitution of niobium $(\mathrm{V})$ atoms by close in size high-spin iron atoms $\mathrm{Fe}(\mathrm{III})\left(\mathrm{R}(\mathrm{Nb}(\mathrm{V}))_{\mathrm{c.n.}-6}=0.064 \mathrm{~nm}, \mathrm{R}(\mathrm{Fe}(\mathrm{II}))_{\mathrm{c.n-}-6}=0.061 \mathrm{~nm}\right.$ (L.S.) and $0.078 \mathrm{~nm}$ (H.S.), $\mathrm{R}(\mathrm{Fe}(\mathrm{III}))_{\text {c.n. }-6}=0.055 \mathrm{~nm}$ (L.S.) and $0.0645 \mathrm{~nm}($ H.S.)) [20].

\subsection{NEXAFS spectroscopy}

To determine the charge state of doped iron atoms by NEXAFS (near-edge X-ray absorption fine structure) spectroscopy), $\mathrm{Fe}, \mathrm{Mg}$-codoped bismuth niobate pyrochlore and iron oxides $\mathrm{FeO}$ [21], $\mathrm{Fe}_{2} \mathrm{O}_{3}$ and $\mathrm{Fe}_{3} \mathrm{O}_{4}$ were investigated. All measurements were performed by the method of total quantum output (TEY, total electron yield) on the RussianGerman channel of the BESSY-II synchrotron source in Berlin [19]. Fe2p-absorption spectra are shown in Fig. 2. The basic spectral features of the investigated samples practically coincide both in the number and in the energy position of the basic absorption bands. Moreover, they are almost identical to the $\mathrm{Fe} 2 \mathrm{p}$-spectrum of $\mathrm{Fe}_{2} \mathrm{O}_{3}$ oxide. Based on this, it can be assumed that iron atoms in magnesium-bismuth niobate solid solutions have the charge state of $\mathrm{Fe}^{3+}$. Due to the fact 


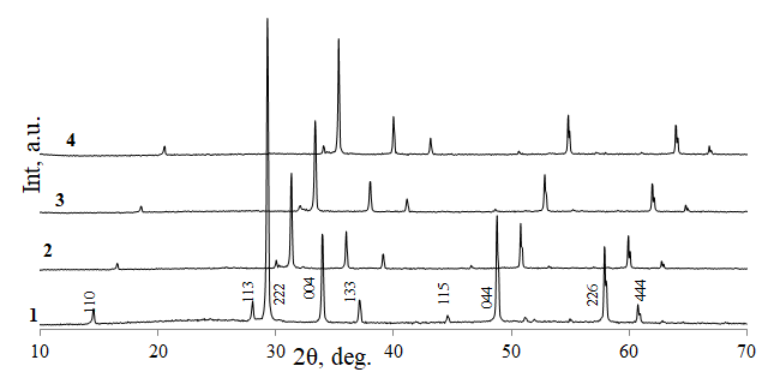

a

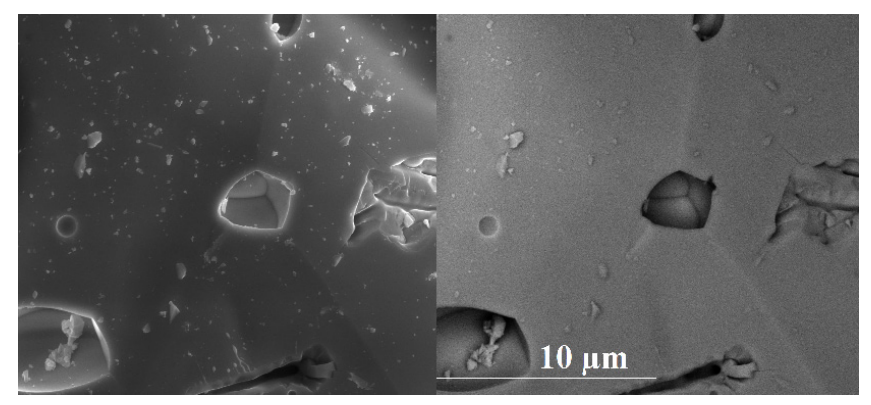

b

Fig. 1. X-ray diffraction patterns of $\mathrm{Bi}_{2} \mathrm{MgNb}_{2-2 x} \mathrm{Fe}_{2 x} \mathrm{O}_{9-\delta}$ at $x=0$ (1), 0.01(2), 0.03(3), 0.06(4) (a); Microphotograph of the $\mathrm{Bi}_{2} \mathrm{MgNb}_{2-2 x} \mathrm{Fe}_{2 x} \mathrm{O}_{9-\delta}$ (0.06) samples in the mode of secondary and elastically reflected electrons.

that iron cations in iron oxides (II, III) occupy octahedral positions, we can conclude that iron ions in $\mathrm{Fe}, \mathrm{Mg}$-codoped bismuth niobate pyrochlore also have a coordination equal to six and point out the tendency of iron ions (III) to occupy octahedral positions $[22,23]$.

\subsection{Magnetic properties}

The paramagnetic components of the magnetic susceptibility $\left[\chi^{\text {para }}(\mathrm{Fe})\right]$ and the values of the effective magnetic moments $\left[\mu_{\mathrm{ef}}(\mathrm{Fe})\right]$ of iron atoms at different temperatures and for different concentrations of solid solutions have been calculated based on the measurements of magnetic susceptibility of the solid solutions. Diamagnetic corrections in the calculation of the paramagnetic component of magnetic susceptibility were introduced taking into account the susceptibility of $\mathrm{Bi}_{2} \mathrm{MgNb}_{2-2 x} \mathrm{Fe}_{2 x} \mathrm{O}_{9-\delta}$, a bismuth niobate matrix measured in the same temperature range. The dependence of the paramagnetic susceptibility inverse value $\left(1 / \chi_{\mathrm{Fe}}{ }^{\text {para }}\right)$ on temperature is linear over the entire temperature range and satisfies the Curie-Weiss law. The Curie-Weiss constant of the solid solution is negative, indicating the dominant antiferromagnetic interactions between paramagnetic atoms. For $\mathrm{Bi}_{2} \mathrm{MgNb}_{2-2 x} \mathrm{Fe}_{2 x} \mathrm{O}_{9-\delta}$ solid solutions it is $-11.2(x=0.005)$ and $-26.7 \mathrm{~K}(0.06)$ and decreases significantly with an increase in the content of iron atoms. Isotherms of the paramagnetic component of the magnetic susceptibility of iron atoms are typical for antiferromagnetics and are shown in Fig. 3 a.

The value of the effective magnetic moment of single iron atoms, calculated as a result of extrapolation of the concentration dependencies of $\left[\chi^{\text {para }}(\mathrm{Fe})\right]$ values for infinite dilution of solid solutions of $\mathrm{Bi}_{2} \mathrm{MgNb}_{2-2 x} \mathrm{Fe}_{2 x} \mathrm{O}_{9-\delta}$ increases with a temperature rise from $7.99 \mu \mathrm{B}(90 \mathrm{~K})$ to $8.27 \mu \mathrm{B}(320 \mathrm{~K})$. For iron atoms (III), the magnetic moment is overestimated with respect to the pure spin value of $\mathrm{Fe}(\mathrm{III})\left(\mu_{\mathrm{ef}}=5.92 \mu \mathrm{B}\right.$, therm $\left.{ }^{6} \mathrm{~A} 1_{\mathrm{g}}\right)$ and $\mathrm{Fe}(\mathrm{II})\left(\mu_{\mathrm{ef}}=4.9 \mu \mathrm{B},{ }^{5} \mathrm{~T}_{2 \mathrm{~g}}\right)$ atoms. This fact cannot be caused by either spin-orbital interaction or zero field effects. Thus, it remains to assume that in highly diluted solutions with a pyrochlore structure there are metabolically bound aggregates or clusters of iron atoms with predominantly ferromagnetic exchange. A decrease in the paramagnetic component of the magnetic susceptibility of iron atoms with an increase in the concentration of solid solutions is associated

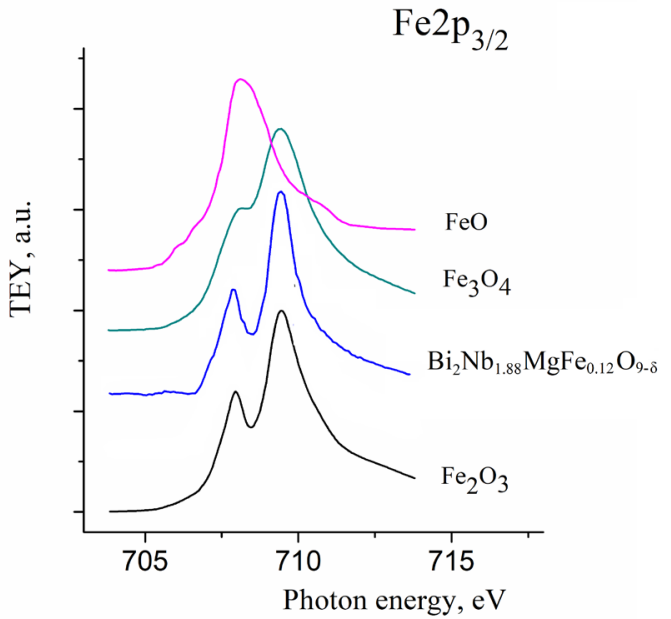

Fig. 2. (Color online) NEXAFS Fe2p- spectra of $\mathrm{Bi}_{2} \mathrm{MgNb}_{2-2 x} \mathrm{Fe}_{2 x} \mathrm{O}_{9-\delta}$ (0.06) and iron oxides $\mathrm{FeO}$ [31], $\mathrm{Fe}_{2} \mathrm{O}_{3}$ and $\mathrm{Fe}_{3} \mathrm{O}_{4}$.

with the manifestation of antiferromagnetic interactions between iron atoms. This assumption is also supported by the temperature dependence of the effective magnetic moment of iron atoms in solid solutions with different concentrations of paramagnetic atoms (Fig. $3 \mathrm{~b}$ ).

To clarify the nature of the distribution of iron atoms in solid solutions and describe metabolic interactions in clusters depending on the content of paramagnetics, a theoretical calculation of the susceptibility and the obtained values were compared with experimental ones. The experimental dependencies of $\chi^{\mathrm{para}}(\mathrm{Fe})$ on the concentration of solid solutions were calculated within the framework of the diluted solid solution model, according to which the magnetic susceptibility is determined as the sum of contributions from single paramagnetic atoms and their exchange-bound aggregates [24]. Taking into account the values of the effective magnetic moment at infinite dilution, its temperature dependence, as well as the features of the crystalline structure of solid solutions, it was assumed that, at infinite dilution, in the solution, in addition to single iron atoms (III), there may be present clusters of two, three or four iron atoms with different types of magnetic exchange. The formula for calculating the paramagnetic component of the magnetic susceptibility of iron atoms in this case is a sum of contributions of the magnetic susceptibility of 


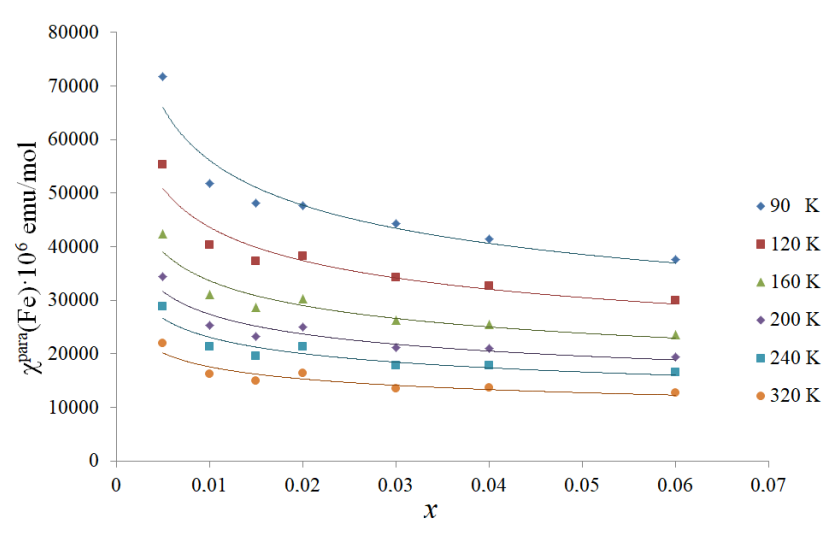

a

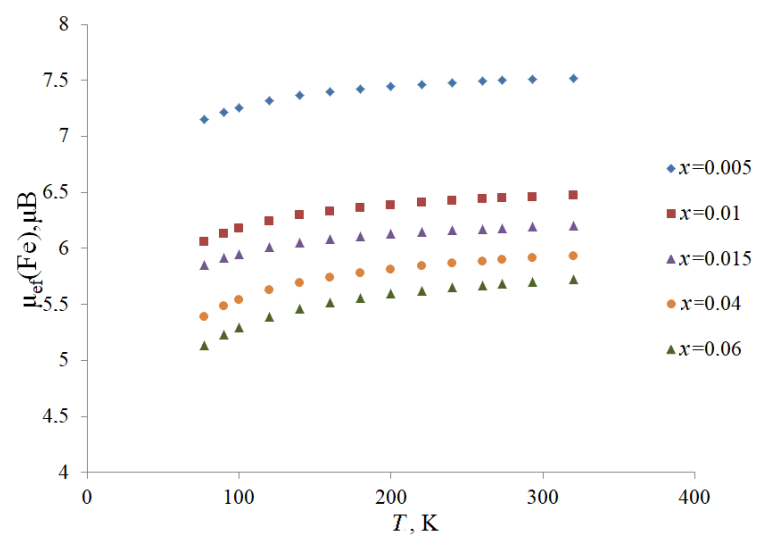

$\mathrm{b}$

Fig. 3. (Color online) Isotherms of the paramagnetic component of the magnetic susceptibility of the $\mathrm{Bi}_{2} \mathrm{MgNb}_{2-2 x} \mathrm{Fe}_{2 x} \mathrm{O}_{9-\delta}$ solid solutions at $90,120,160,200,240$ and $320 \mathrm{~K}$ (a); Temperature dependences of the magnetic moment of iron atoms in $\mathrm{Bi}_{2} \mathrm{MgNb}_{2-2 x}^{2-2 x} \mathrm{Fe}_{2 x} \mathrm{O}_{9-\delta}$ at $x=0.005$, $0.01,0.015,0.04$ and $0.06(\mathrm{~b})$.

monomers, dimers, trimers and tetramers with antiferro- and ferromagnetic type of exchange:

$$
\begin{aligned}
& \chi_{\mathrm{calc}}^{\mathrm{para}}(\mathrm{Fe})=a_{\mathrm{Fe}(\mathrm{III})}^{\operatorname{mon}} \chi_{\mathrm{Fe}(\mathrm{III})}^{\operatorname{mmon}}+a_{\mathrm{Fe}(\mathrm{III})}^{\operatorname{dim}(f)} \chi_{\mathrm{Fe}(\mathrm{III})}^{\operatorname{dim}(f)}+a_{\mathrm{Fe}(\mathrm{III})}^{\operatorname{dim}(a)} \chi_{\mathrm{Fe}(\mathrm{III})}^{\operatorname{dim}(a)}+ \\
&+a_{\mathrm{Fe}(\mathrm{III})}^{\operatorname{trim}(f)} \chi_{\mathrm{Fe}(\mathrm{III})}^{\operatorname{trim}(f)}+a_{\mathrm{Fe}(\mathrm{III})}^{\operatorname{trim}(a)} \chi_{\mathrm{Fe}(\mathrm{III})}^{\operatorname{trim}(a)}+ \\
&+a_{\mathrm{Fe}(\mathrm{III})}^{\operatorname{tetr}(a)} \chi_{\mathrm{Fe}(\mathrm{III})}^{\operatorname{tetr}(a)}+a_{\mathrm{Fe}(\mathrm{III})}^{\operatorname{tet}(f)} \chi_{\mathrm{Fe}(\mathrm{III})}^{\operatorname{tet}(f)}, \\
& a_{\mathrm{Fe}(\mathrm{III})}^{\operatorname{mon}}+a_{\mathrm{Fe}(\mathrm{III})}^{\operatorname{dim}(f)}+a_{\mathrm{Fe}(\mathrm{III})}^{\operatorname{dim}(a)}+a_{\mathrm{Fe}(\mathrm{III})}^{\operatorname{trim}(f)}+a_{\mathrm{Fe}(\text { III) }}^{\operatorname{trim}(a)}+a_{\mathrm{Fe}(\mathrm{III})}^{\operatorname{tet}(a)}+a_{\mathrm{Fe}(\text { III) }}^{\operatorname{tetr}(f)}=1 .
\end{aligned}
$$

Here, $a_{\mathrm{Fe}(\mathrm{III})}^{\operatorname{mon}}, a_{\mathrm{Fe}(\mathrm{III})}^{\operatorname{dim}(f)}, a_{\mathrm{Fe}(\text { III) }}^{\operatorname{dim}(a)}, a_{\mathrm{Fe}(\mathrm{III})}^{\operatorname{trim}(f)}, a_{\mathrm{Fe}(\mathrm{III})}^{\operatorname{trim}(a)}, a_{\mathrm{Fe}(\mathrm{III})}^{\operatorname{tetr}(a)}$ and $a_{\mathrm{Fe}(\mathrm{III})}^{\operatorname{tetr}(f)}$ are the fractions of monomers, dimers, trimers and tetramers of $\mathrm{Fe}$ (III) atoms with ferromagnetic - and antiferromagnetic types of interaction, $\chi_{\mathrm{Fe}(\mathrm{III})}^{\operatorname{mon}}, \chi_{\mathrm{Fe}(\mathrm{III})}^{\operatorname{dim}(f)}, \chi_{\mathrm{Fe}(\mathrm{III})}^{\operatorname{dim}(a)}, \chi_{\mathrm{Fe}(\mathrm{III})}^{\operatorname{tri}(f)}, \chi_{\mathrm{Fe}(\mathrm{III})}^{\operatorname{trim}(a)}$, $\chi_{\mathrm{Fe}(\mathrm{III})}^{\mathrm{tetr}(f)}, \quad \chi_{\mathrm{Fe}(\mathrm{III})}^{\mathrm{tetr}(a)}$ are magnetic susceptibilities of monomers, dimers, trimers and tetramers with ferromagnetic and antiferromagnetic exchange.

According to the Heisenberg-Dirac-Van-Vleck model [25], the magnetic susceptibility of tetramers consisting of paramagnetic atoms was calculated by formula (3):

$$
\chi_{\text {tetr }}^{S_{1}-S_{2}}=\frac{1}{4} \frac{\sum_{S^{\prime}} \sum_{S_{12}} \sum_{S_{34}} g^{2}\left(S^{\prime}\right) S^{\prime}\left(S^{\prime}+1\right)\left(2 S^{\prime}+1\right) e^{-E\left(J, S^{\prime}\right) / k T}}{8 T \sum_{S^{\prime}} \sum_{S_{12}} \sum_{S_{34}}\left(2 S^{\prime}+1\right) e^{-E\left(J, S^{\prime}\right) / k T}},
$$

where

$$
\begin{gathered}
E(J, S)=-J\left[S^{\prime}\left(S^{\prime}+1\right)-4 S_{1}\left(S_{1}+1\right)\right], \\
S_{12}=S_{1}+S_{2}, S_{1}+S_{2}-1, \ldots,\left|S_{1}-S_{2}\right|, \\
S_{34}=S_{3}+S_{4}, S_{3}+S_{4}-1, \ldots,\left|S_{3}-S_{4}\right|, \\
S^{\prime}=S_{12}+S_{34}, S_{12}+S_{34}-1, \ldots,\left|S_{12}-S_{34}\right| .
\end{gathered}
$$

Here, $S_{1}$ and $S_{2}, S_{3}$ and $S_{4}$ - the spin values of the atoms that form tetramers, in our case $S_{1}=S_{2}=S_{3}=S_{4}=5 / 2$ for the tetrameter $\mathrm{Fe}$ (III)-O-Fe(III)-O-Fe(III)-O-Fe(III), $S^{\prime}$ and $S_{12}$ and $S_{34}$ - values of total spin and intermediate moments, $g$ - Lande factor for iron (III), $J$ - exchange parameter, $T$ - absolute temperature.

The alignment of the calculated and experimental values is achieved by minimizing the function $\sum_{i} \sum_{j}\left(\chi_{i j}^{\text {calc }}-\chi_{i j}^{\text {exp }}\right)^{2}$, where $\sum_{i}$ - summation by all concentrations; $\sum_{j}-$ temperature totaling; $\chi_{i j}^{\text {calc }}, \chi_{i j}^{\exp }-$ experimental ${ }^{j}$ and calculated values of paramagnetic component of magnetic susceptibility of solid solutions.
Best agreement of experimental and calculation data for $\mathrm{Bi}_{2} \mathrm{MgNb}_{2-2 x} \mathrm{Fe}_{2 x} \mathrm{O}_{9-\delta}$ solid solutions were obtained at the values of the antiferromagnetic exchange in dimers $J_{\mathrm{dim}}=-25 \mathrm{~cm}^{-1}$, trimers $J_{\text {trim }}=-14 \mathrm{~cm}^{-1}$ and tetramers $J_{\text {tetr }}=-9 \mathrm{~cm}^{-1}$; ferromagnetic exchange in dimers $-J_{\mathrm{dim}}=20 \mathrm{~cm}^{-1}$, trimers $J_{\text {trim }}=16 \mathrm{~cm}^{-1}$ and tetramers $J_{\text {tetr }}=11 \mathrm{~cm}^{-1}$. The results of a comparison between the experimental and theoretical values of the magnetic susceptibilities of solid solution are given in Table 1.

As a result of the studies of iron-containing solid solutions, it was found that in an infinitely diluted solid solution, iron atoms (III) are mainly in an aggregate state and form dimers, trimers and tetramers with antiferro- and ferromagnetic type of exchange. Apparently, the formation of clusters of iron atoms (III) in an infinitely diluted solid solution contributes to the stabilization of the structure of heterovalent substitution solid solutions by including oxygen vacancies in the cluster or localization of the cluster near it. The possibility of ferromagnetic exchange, which is atypical for iron atoms (III), is due to geometric distortions in the polyhedral environment of iron atoms caused by anionic vacancies. The probability of realizing ferromagnetic exchange is high through cross-exchange channels, for example, $d_{x^{2}-y^{2}} \perp p_{x} \perp d_{x y}, d_{x^{2}-y^{2}}\left\|p_{x} \perp p_{y}\right\| d_{x y}$, $d_{x y}\left\|p_{y} \perp p_{z}\right\| d_{x z} \quad$ [36]. The formation of clusters with an antiferro - and ferromagnetic type of exchange indirectly indicates the presence of iron atoms (III) in the crystal fields of different symmetry.

It should be noted that, despite a significant share of aggregates in an infinitely diluted solution with a ferromagnetic type of exchange, the exchange as a whole is of an antiferromagnetic character. This is apparently due to a more effective overlap of the orbits involved in the exchange of atoms through the channels of antiferromagnetic exchange, and relatively small geometric distortions in the structure of the solid solutions, causing ferromagnetic exchange. The share of clusters with a ferromagnetic type of exchange decreases with increasing concentration of solid solutions due to averaging of local distortions of the structure and the formation of aggregates mainly with an antiferromagnetic type of exchange.

The relatively low absolute values of the exchange parameters are obviously associated with the competition 
Table 1. The results of calculating the distribution of iron atoms in the $\mathrm{Bi}_{2} \mathrm{MgNb}_{2-2 x} \mathrm{Fe}_{2 x} \mathrm{O}_{9-\delta}$ solid solutions.

\begin{tabular}{|c|c|c|c|c|c|c|c|c|c|c|}
\hline \multirow{2}{*}{$x$} & \multirow{2}{*}{$a_{\mathrm{Fe}(\mathrm{III})}^{\mathrm{tet}(f)}$} & \multirow{2}{*}{$a_{\mathrm{Fe}(\mathrm{III})}^{\operatorname{tet}(a)}$} & \multirow{2}{*}{$a_{\mathrm{Fe}(\mathrm{III})}^{\operatorname{trim}(f)}$} & \multirow{2}{*}{$a_{\mathrm{Fe}(\mathrm{III})}^{\text {mon }}$} & \multirow{2}{*}{$a_{\mathrm{Fe}(\mathrm{III})}^{\operatorname{dim}(f)}$} & \multirow{2}{*}{$a_{\mathrm{Fe}(\mathrm{III})}^{\operatorname{dim}(a)}$} & \multicolumn{4}{|c|}{$\chi_{\text {calc }} / \chi_{\exp } \cdot 10^{3}, \mathrm{emu} / \mathrm{mol}$} \\
\hline & & & & & & & $140 \mathrm{~K}$ & $200 \mathrm{~K}$ & $260 \mathrm{~K}$ & $320 \mathrm{~K}$ \\
\hline 0.005 & 0.20 & 0 & 0.23 & 0.14 & 0.26 & 0.13 & $51.7 / 48.0$ & $33.9 / 34.4$ & $24.5 / 26.8$ & $18.9 / 21.9$ \\
\hline 0.007 & 0.16 & 0.03 & 0.19 & 0.13 & 0.22 & 0.18 & $44.5 / 38.7$ & $29.6 / 27.7$ & $21.7 / 21.5$ & $16.9 / 17.6$ \\
\hline 0.010 & 0.12 & 0.06 & 0.17 & 0.12 & 0.19 & 0.21 & $38.7 / 35.1$ & $26.1 / 25.3$ & $19.4 / 19.8$ & $15.3 / 16.2$ \\
\hline 0.015 & 0.11 & 0.08 & 0.15 & 0.10 & 0.17 & 0.24 & $35.6 / 32.4$ & $24.2 / 23.3$ & $18.1 / 18.2$ & $14.4 / 14.9$ \\
\hline 0.020 & 0.11 & 0.09 & 0.14 & 0.09 & 0.15 & 0.26 & $33.9 / 33.8$ & $23.2 / 24.9$ & $17.5 / 19.8$ & $13.9 / 14.5$ \\
\hline 0.030 & 0.10 & 0.11 & 0.12 & 0.08 & 0.13 & 0.28 & $31.1 / 29.7$ & $21.5 / 21.3$ & $16.3 / 16.6$ & $13.1 / 13.6$ \\
\hline 0.040 & 0.10 & 0.11 & 0.11 & 0.08 & 0.11 & 0.29 & $29.7 / 28.7$ & $20.7 / 20.9$ & $15.8 / 16.5$ & $12.8 / 13.6$ \\
\hline 0.060 & 0.09 & 0.12 & 0.09 & 0.07 & 0.09 & 0.32 & $26.8 / 26.4$ & $18.9 / 19.4$ & $14.6 / 15.3$ & $11.9 / 12.7$ \\
\hline
\end{tabular}

Note: $a_{\mathrm{Fe}(\mathrm{III})}^{\mathrm{tet}(f)} a_{\mathrm{Fe}(\mathrm{III})}^{\mathrm{tetr}(a)}, a_{\mathrm{Fe}(\mathrm{III})}^{\operatorname{trim}(f)}, a_{\mathrm{Fe}(\mathrm{III})}^{\operatorname{mon}}, a_{\mathrm{Fe}(\mathrm{III})}^{\operatorname{dim}(f)}, a_{\mathrm{Fe}(\mathrm{III})}^{\operatorname{dim}(a)}-$ fractions of dimers, trimers and tetramers from iron (III) atoms with antiferro- and ferromagnetic type of exchange.

between the antiferro- and ferromagnetic interactions caused by the pyrochlore structure features, namely, by the nature of the junction of oxygen octahedrons. In the pyrochlore structure, the octahedrons are connected by tops, forming a three-dimensional frame of chains of niobium-oxygen octahedrons. Within the circuits, the $\mathrm{Fe}-\mathrm{O}$-Fe communication angle is less than $180^{\circ}$, namely $135^{\circ}$, which significantly reduces $\mathrm{p}_{\pi}-\mathrm{d}_{\pi}$ overlapping on the antiferromagnetic exchange channels, for example $d_{x y}\left\|p_{y}\right\| d_{x y}$ [26]. In addition, the introduction of iron atoms into the niobium position leads to local distortions of the octahedron, including in the plane perpendicular to the axis connecting the two atoms through oxygen, then the contribution of the second channel of antiferromagnetic exchange will be significantly reduced $d_{x z}\left\|p_{z}\right\| d_{x z}$.

Thus, when replacing niobium atoms, iron atoms (III) are distributed mainly in octahedral positions of niobium. The influence of heterovalent substitution affects the clustering of iron atoms (III). Given the strong distortions of the local environment caused by oxygen vacancies, antiferromagnetic and ferromagnetic exchange between iron atoms occurs, which becomes less significant with increasing concentration of atoms and averaging distortions of the structure.

\section{Conclusions}

Iron-containing solid solutions of the $\mathrm{Bi}_{2} \mathrm{MgNb}_{2-2 x} \mathrm{Fe}_{2 x} \mathrm{O}_{9-\delta}$ pyrochlore structure were obtained by the solid phase synthesis method. The parameter of the unit cell of solid solutions is close to the constant cell for bismuth-magnesium niobate. As a result of the NEXAFS-study of solid solutions and iron oxides, it was found that the main details of the spectra of solid solutions practically coincide with each other both in number and in the energy position of the main absorption bands and are identical to the Fe2p-spectrum of $\mathrm{Fe}_{2} \mathrm{O}_{3}$ oxide. Iron (III) cations are distributed mainly in the octahedral positions of niobium (V) and in a dominant amount are in the charge state of $\mathrm{Fe}$ (III) in the form of monomers and exchange-bound clusters mainly with an antiferromagnetic type of exchange. As a result of calculating the parameters of metabolic interactions in clusters and the distribution of paramagnetic iron atoms depending on the content of paramagnetic atoms, the presence of high nuclear clusters with indirect antiferro- and ferromagnetic types of interaction in heavily diluted solid solutions was found. With increasing concentrations of solid solutions, the nuclearity and the proportion of antiferromagnetically bound aggregates increase.

Acknowledgements. The authors are grateful to the employee of the Institute of Chemistry, St. Petersburg State University, Chezhina N. V. for the opportunity to measure the magnetic susceptibility of samples.

\section{References}

1. G. Giampaoli, T. Siritanon, B. Day, J.Li, M. A. Subramanian. Prog. Sol. St. Chem. 50, 16 (2018). Crossref

2. F. Matteucci, G. Cruciani, M. Dondi, G. Baldi, A. Barzanti. Acta Mater. 55, 2229 (2007). Crossref

3. M. A. Subramanian, G. Aravamudan, G. V. Subba Rao. Prog. Sol. St. Chem. 15, 55 (1983). Crossref

4. Z. Hiroi, J.-I. Yamaura, S. Yonezawa, H. Harima. Physica C: Superconductivity and Appl. 460-462, 20 (2007). Crossref

5. Z. Zou, J. Ye, H. Arakawa. Mater. Sci. Engineer.: B. 79, 83 (2001). Crossref

6. R. A. McCauley. J. Appl. Phys. 51, 290 (1980). Crossref

7. C. C. Khaw, K. B. Tan, C. K. Lee, A. R. West. J. Eur. Ceram. Soc. 32, 671 (2012). Crossref

8. M. Valant, D. Suvorov. J. Am. Ceram. Soc. 88, 2540 (2005). Crossref

9. T. A. Vanderah, T. Siegrist, M. W. Lufaso, M.C. Yeager, R.S. Roth, J.C. Nino, S. Yates. Eur. J. Inorgan. Chem. 2006, 4908 (2006). Crossref

10. M. C. Blanco, D. G. Franco, Y. Jalit, E. V. Pannunzio Miner, G. Berndt, Jr. A. Paesano, G. Nieva, R. E. Carbonio. Phys. B: Cond. Mat. 407, 3078 (2012). Crossref

11. Y. Zhang, Z. Zhang, X. Zhu, Z. Liu, Y. Li, T. Al-Kassab. Appl. Phys. A. 115, 661 (2013). Crossref

12. Y.X. Jin, L.X. Li, H.L. Dong, S.H. Yu, D.Xu. J. Alloys Comp. 622, 200 (2015). Crossref

13. P.Y. Tan, K. B. Tan, C.C. Khaw, Z. Zainal, S. K. Chen, M. P. Chon. Ceram. Intern. 40, 4237 (2014). Crossref

14. Q. Guo, L. Li, S. Yu, Z. Sun, H. Zheng, W. Luo. J. Alloys Comp. 767, 259 (2018). Crossref

15. A. Hassan, G. M. Mustafa, S. K. Abbas, S. Atiq, M. Saleem, S. Riaz, S. Naseem. Ceram. Intern. 45, 14576 (2019). Crossref

16. Q. Guo, L. Li, S. Yu, Z. Sun, H. Zheng, J. Li, W. Luo. Ceram. Intern. 44, 333 (2018). $\underline{\text { Crossref }}$ 
17. S. Yu, L. Li, H. Zheng. J. Alloys Comp. 699, 68 (2017). Crossref

18. L. G. Akselrud, Yu. N. Grin, P. Yu. Zavalii, V.K. Pecharski, V.S. Fundamentski. CSD, an universal program package for single crystal and/or powder structure data treatment. Twelfth European Crystallogr. Meeting, Collected Abstracts. Moscow (1989).

19. J. Stohr. NEXAFS Spectroscopy. Springer, Berlin (1992). Crossref

20. R.D. Shannon. Acta Crystallogr. A. 32, 751 (1976). Crossref

21. T. J. Regan, H. Ohldag, C. Stamm, F. Nolting, J. Luning, J. Stöhr, R.L. White. Phys. Rev. B. 64, 214422 (2001). Crossref

22. N. A. Zhuk, M. V. Yermolina, V.P. Lutoev, B. A. Makeev, E. A. Belyaeva, N. V. Chezhina. Ceram. Intern. 43, 16919 (2017). Crossref
23. N.A. Zhuk, V.P. Lutoev, B. A. Makeev, N.V. Chezhina, V.A. Belyy, S. V. Nekipelov. Rev. Adv. Mater. Sci. 57, 35 (2018). Crossref

24. N. V. Chezhina, N. A. Zhuk. Russ. J. Gen. Chem. 85, 2520 (2015). Crossref

25. V.G. Kalinnikov, Yu. V. Rakitin. Introduction to Magnetochemistry. Method of Static Magnetic Susceptibility in Chemistry. Nauka, Moscow (1980) 302 p. (in Russian) [В.Г. Калинников, Ю. В. Ракитин. Введение в магнитохимию. Метод статистической магнитной восприимчивости в химии. Наука, Москва (1980) 302 с.]

26. D. Goudenath. Magnetism and chemical bonding. Moscow, Metallurgiya (1968). (in Russian) [Д. Б. Гуденаф. Магнетизм и химическая связь. Москва, Металлургия (1986).] 